\title{
Morphological Traits of Silver Fir (Abies alba Mill.) in the Bosnian-Herzegovinian Provenance Test
}

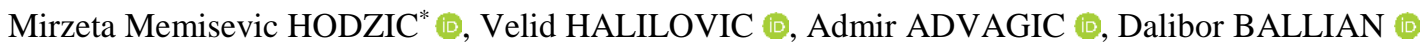 \\ University of Sarajevo, Faculty of Forestry, BOSNIA and HERZEGOVINA \\ *Corresponding Author: m.memisevic-hodzic@sfsa.unsa.ba
}

Received Date: 11.01 .2021

Accepted Date: 28.04 .2021

Abstract

Aim of study: This research aims to determine if there are statistically significant differences among provenances of silver fir (Abies alba Mill.) as one of the most important tree species in Bosnia and Herzegovina, to choose a provenance with the best productivity for further silvicultural activities of silver fir in the country.

Material and methods: The height and diameter at breast height were measured, and the basal area and volume of silver fir trees were calculated in the silver fir provenance test. The test contains nine provenances from Bosnia and Hezegovina and was launched in 1991, with 5-year-old seedlings $(3+2)$. The data were collected in 2013.

Main results: Variance analysis for all traits showed statistically significant differences among provenances. Average breast height diameter in 27-year-old plants for all provenances amounted to 11.0 $\mathrm{cm}$, average height $8.4 \mathrm{~m}$, average basal area $0.010342 \mathrm{~m}^{2}$, and average volume $0.070845 \mathrm{~m}^{3}$

Highlights: The research results confirmed the existence of variability among silver fir provenances in Bosnia and Herzegovina, considering the morphological indicators. Provenance Bosanski Petrovac showed the highest values of all traits, which implies it is the best provenance for the further activities on seed collecting and producing planting material for afforestation in Bosnia and Herzegovina.

Keywords: Morphological Traits, Provenance Test, Silver Fir

\section{Bosna-Hersek Orijin Testinde Gümüşi Göknarın (Abies alba Mill.) Morfolojik Özellikleri}

Öz

Çalışmanın amact: $\mathrm{Bu}$ araştırmada, Bosna Hersek'in önemli ağaç türlerinden biri olan Gümüşi Göknar'ın (Abies alba Mill.) farklı orijinleri arasında istatistiksel olarak önemli farklılıklar olup olmadığı ve bu sonuçlar neticesinde Gümüşi Göknar'ın ileri ki silvikültürel uygulamalar için hangi orijinin en iyi verimliliğe sahip olduğu belirlenmeye çalışılmıştır.

Materyal ve yöntem: Gümüşi Göknar'ın farklı orijinlerinde göğüs yüksekliğindeki boy ve çapları, göğüs yüzey alanı ve hacimleri hesaplanmıştır. Ölçümler, 1991 yılında Bosna Hersek'in 9 farklı orijininden alınan 5 yaşında ki (3+2) fidanlarda yapılmıştır. Daha sonra tüm veriler 2013 yılında toplanmıştır.

Temel sonuçlar: Tüm gruplar için varyans analizi yapılmış ve deney yapılan 9 orijin arasında istatistiksel olarak anlamlı farklılıklar bulunmuştur. 27 yaşındaki ağaçlarda tüm orijinler için ortalama gögüs yüksekliği çap1 $11,0 \mathrm{~cm}$, ortalama yükseklik $8,4 \mathrm{~m}$, ortalama göğüs yüzey alanı $0,010342 \mathrm{~m}^{2}$ ve ortalama hacim $0,070845 \mathrm{~m}^{3}$ olarak belirlenmiştir.

Araştırma vurguları: Morfolojik göstergeler göz önüne alındığında araştırma sonuçları Bosna Hersek'teki Gümüşi Göknar orijinleri arasında farklılıklar olduğu saptanmıştır. Bosanski Petrovac orijinli deney örneklerinde tüm özellikler bakımından en yüksek değerler tespit edilmiş ve bu orijinin BosnaHersek'te tohum toplamada ve ağaçlandırmada kullanılmak üzere dikim materyali üretme ve daha sonraki faaliyetler için en iyi kaynak olduğu sonucuna varılmıştır.

Anahtar Kelimeler: Morfolojik Özellikler, Orijin Testi, Gümüşi Göknar 


\section{Introduction}

Silver fir (Abies alba Mill.) is one of the most important species of forest trees from an economic and ecological point of view in Bosnia and Herzegovina (Ballian \& Čabaravdić, 2005; Ballian \& Halilović, 2016).

The main area of distribution of silver fir in Bosnia and Herzegovina is along the Dinaric mountains, in several separate, larger and smaller, areas (Fukarek, 1970). The total area of the forests where silver fir exists (pure and mixed forests), is 562.237 ha., or about $50 \%$ of all managed forests. The total growing stock of silver fir in these forests is $63.923 .000 \mathrm{~m}^{3}$, which is about $23 \%$ of the total wood stock in all managed forests (Usčuplić, 1992).

Provenance tests are widely known as a special type of plantation experiment that helps experts to understand how trees are adapted to different environmental conditions through genetic adaptation or phenotypic plasticity. For that reason, the BosnianHerzegovinian provenance test of silver was set in 1991.

The provenance that grows best can be considered best adapted to the planting site conditions and recommended for reforestation on sites that are similar to the test environment. Despite their useful results, provenance tests are very expensive long-term research, and comprehensive trial series is only possible for the most valuable forest tree species in the area.
The research aim is to evaluate the dynamics of the growth of silver fir provenances in Bosnia and Herzegovina by comparing morphological traits of height and breast height diameter, to choose a provenance with the best productivity for further silvicultural activities.

\section{Material and Methods}

The subject of this study were silver fir trees in the Bosnian provenance test. The provenance test was established on experimental plot Delimusa in forest management area Olovsko, forest management unit Krivaja, department 86, section a.

The experimental plot is located at an altitude of $970 \mathrm{~m}$., on the northern exposure and inclination of the terrain in the interval of 10-20 degrees, on the deep acid brown soil on silicate substrate.

The starting material for the experiment originated from nine locations in Bosnia and Herzegovina (Bosanski Petrovac, Bugojno, Fojnica, Konjic, Olovo - Klis, Olovo-Palež, Pale, Prozor, and Sokolac) from positions between 850 and $1300 \mathrm{~m}$. above sea level. The northernmost provenance comes from Bosanski Petrovac, while the southernmost comes from the area of Herzegovina - Konjic. the geographical distribution of populations used as starting material in the provenance test is shown in Figure 1, and their basic characteristics are showed in Table 1.

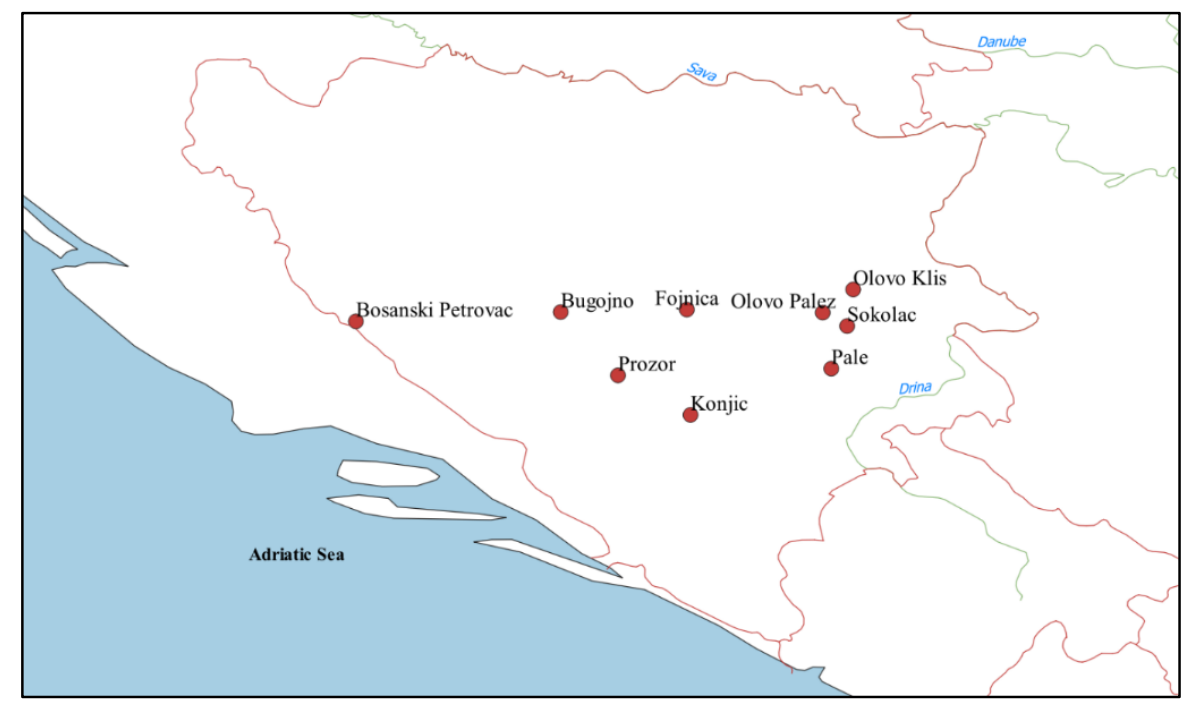

Figure 1. Geographical distribution of populations used as starting material 
Table 1. Basic characteristics of populations used as starting material in provenance test

\begin{tabular}{|c|c|c|c|c|c|c|c|}
\hline Provenance & Soil Type & $\begin{array}{c}\text { Geological- } \\
\text { petrographic } \\
\text { Substrate }\end{array}$ & $\begin{array}{l}\text { Altitude } \\
\text { (m) }\end{array}$ & Exposure & $\begin{array}{c}\text { Inclination } \\
(\%)\end{array}$ & Latitude & Longitude \\
\hline $\begin{array}{l}\text { Bosanski } \\
\text { Petrovac }\end{array}$ & $\begin{array}{c}\text { Rendsina } \\
\text { calcocambisol } \\
\text { pseudogley }\end{array}$ & Dolomites & 900 & $\mathrm{~N}$ & 2 & $44^{\circ} 29^{\prime} 16^{\prime \prime}$ & $16^{\circ} 27^{\prime} 21^{\prime \prime}$ \\
\hline Bugojno & $\begin{array}{c}\text { Rendsina } \\
\text { calcocambisol }\end{array}$ & $\begin{array}{l}\text { Dolomites and } \\
\text { Limestones }\end{array}$ & 1.090 & $\mathrm{~N}-\mathrm{W}$ & $10-25$ & $43^{\circ} 59^{\prime} 29^{\prime \prime}$ & $17^{\circ} 22^{\prime} 27^{\prime \prime}$ \\
\hline Fojnica & Dystric cambisol & Rhyolite & 1.010 & $\mathrm{~N}$ & $10-15$ & $43^{\circ} 55^{\prime} 57^{\prime \prime}$ & $17^{\circ} 53^{\prime} 48^{\prime \prime}$ \\
\hline Konjic & $\begin{array}{l}\text { Calcocambisol } \\
\text { calcomelanosol }\end{array}$ & $\begin{array}{c}\text { Dense } \\
\text { limestones }\end{array}$ & 1.030 & E-EN & $10-22$ & $43^{\circ} 32^{\prime} 22^{\prime \prime}$ & $18^{\circ} 01^{\prime} 06^{\prime \prime}$ \\
\hline $\begin{array}{l}\text { Olovo - } \\
\text { Klis }\end{array}$ & $\begin{array}{c}\text { Calcocambisol } \\
\text { luvisol }\end{array}$ & Limestones & 850 & $\mathrm{~N}-\mathrm{W}$ & 13 & $44^{\circ} 08^{\prime} 12^{\prime \prime}$ & $18^{\circ} 42^{\prime} 27^{\prime \prime}$ \\
\hline $\begin{array}{l}\text { Olovo - } \\
\text { Palež }\end{array}$ & $\begin{array}{c}\text { Calcocambisol } \\
\text { luvisol }\end{array}$ & Limestones & 960 & N-E & 12 & $44^{\circ} 03^{\prime} 04^{\prime \prime}$ & $18^{\circ} 37^{\prime} 07^{\prime \prime}$ \\
\hline Pale & $\begin{array}{c}\text { Dystric cambisol } \\
\text { calcomelanosol }\end{array}$ & $\begin{array}{l}\text { Werfenian } \\
\text { schists } \\
\text { Sandstones } \\
\text { Limestones }\end{array}$ & 1.200 & N-E & 20 & $43^{\circ} 48^{\prime} 02^{\prime \prime}$ & $18^{\circ} 32^{\prime} 51^{\prime \prime}$ \\
\hline Prozor & $\begin{array}{c}\text { Calcomelanosol } \\
\text { luvisol }\end{array}$ & $\begin{array}{l}\text { Limestone } \\
\text { moraine }\end{array}$ & 1.300 & N-E & $5-10$ & $43^{\circ} 40^{\prime} 39^{\prime \prime}$ & $17^{\circ} 37^{\prime} 31^{\prime \prime}$ \\
\hline Sokolac & $\begin{array}{l}\text { Calcocambisol } \\
\text { calcomelanosol }\end{array}$ & Limestones & 940 & S-W & 13 & $43^{\circ} 53^{\prime} 42^{\prime \prime}$ & $18^{\circ} 42^{\prime} 17^{\prime \prime}$ \\
\hline
\end{tabular}

Collection of seed from these provenances was carried out in autumn 1985, after which sowing was done in the nursery Zavidovići. The seedlings of the age of $3+2$ were planted in the experimental plot in the spring of 1991. A block system with five repetitions was chosen for planting. Dimensions of the plot are $173 \mathrm{~m} \times 88 \mathrm{~m}=1,522 \mathrm{ha}$, and on each side of the plot, two rows of the same tree species were planted. These rows serve as a protective band so that the total area of the experimental plot is approximately 2 hectares.

Each of the five blocks was divided into ten plots with dimensions $14 \times 14$ meters. There are 3-meter interspaces among plots on each side, and seedlings were planted with 2 meters' distance.

A total of 2880 seedlings (64 seedlings per provenance and block) were planted. Each provenance consists of 15 families, and each family has four plants.
In this research, we measured heights and diameters at breast height (DBH - $1.30 \mathrm{~m}$ from the ground) of silver fir trees in the provenance test. Basal area and volume of tress were read from Tables for measuring elements in high and coppice forests in Bosnia and Herzegovina (Matić et al., 1990), with two inputs: DBH and height. Measurements were made in 2013, at plant age 27 years.

We processed obtained data by statistical program SPSS 20.0. We calculated descriptive indicators (mean, minimum, maximum, standard deviation, coefficient of variability) and completed variance analysis and Duncan test per provenances. Univariate analysis was performed to include effects of blocks, provenances, and block x provenance interaction.

\section{Results and Discussion}

Descriptive statistics for DBH $(\mathrm{cm})$ per provenances are shown in Table 2. 
Table 2. Descriptive indicators for diameter at breast height $(\mathrm{cm})$ per provenances

\begin{tabular}{lcccccc}
\hline Provenance & $\mathrm{N}$ & Mean & $\begin{array}{c}\text { Standard } \\
\text { Deviation }\end{array}$ & Minimum & Maximum & $\begin{array}{c}\text { Variability } \\
\text { Coefficient }(\%)\end{array}$ \\
\hline Bosanski Petrovac & 218 & 11.9 & 3.4 & 2.5 & 19.3 & 28.3 \\
\hline Bugojno & 248 & 10.8 & 3.0 & 3.0 & 20.2 & 28.1 \\
\hline Fojnica & 271 & 11.2 & 3.3 & 3.3 & 19.8 & 29.4 \\
\hline Konjic & 258 & 10.7 & 2.8 & 4.3 & 21.3 & 25.8 \\
\hline Olovo-Klis & 204 & 11.1 & 2.7 & 3.4 & 18.7 & 24.7 \\
\hline Olovo Palež & 258 & 10.8 & 3.2 & 3.3 & 21.5 & 29.7 \\
\hline Pale & 243 & 10.8 & 3.2 & 3.5 & 20.0 & 29.5 \\
\hline Prozor & 251 & 10.8 & 3.2 & 3.5 & 21.6 & 30.0 \\
\hline Sokolac & 248 & 11.2 & 3.2 & 1.7 & 18.2 & 28.2 \\
\hline Total & 2199 & 11.0 & 3.1 & 1.7 & 21.6 & 28.5 \\
\hline
\end{tabular}

The average DBH for all provenances was $11.0 \mathrm{~cm}$. Konjic provenance had the lowest average breast height diameter, $10.7 \mathrm{~cm}$, and Bosanski Petrovac provenance the highest, $11.9 \mathrm{~cm}$.

The average coefficient of variability for all provenances was $28.5 \%$. The highest coefficient of variation had the provenance of Prozor, $30.0 \%$, and the lowest provenance of Olovo - Klis, $24.7 \%$.

The variance analysis showed statistically significant differences among provenances for DBH at 0.05 level (Table 3).

Table 3. Analysis of variance for diameter at breast height

\begin{tabular}{lccccc}
\hline Source of Variation & Sum of Squares & DF & Mean Square & F & Sig. \\
\hline Between Groups & 281.920 & 8 & 35.240 & 3.610 & 0.000 \\
\hline Within Groups & 21378.254 & 2190 & 9.762 & & \\
\hline Total & 21660.174 & 2198 & & & \\
\hline
\end{tabular}

According to Duncan's test for DBH (Table 4), provenances are divided into two groups, i.e. provenance Bosanski Petrovac separates from other provenances. Descriptive statistics for heights $(\mathrm{m})$ per provenances are shown in Table 5. The average height in all the provenances was $8.4 \mathrm{~m}$. Provenances Konjic, Olovo-Klis, and Pale had the lowest average height, $8.1 \mathrm{~m}$, and Bosanski Petrovac the highest average height, $9.1 \mathrm{~m}$.
Table 4. Duncan test for DBH

\begin{tabular}{|c|c|c|c|}
\hline \multirow{2}{*}{ Provenance } & \multirow{2}{*}{$\mathrm{N}$} & \multicolumn{2}{|c|}{ Subset for Alpha $=0.05$} \\
\hline & & 1 & 2 \\
\hline Konjic & 258 & 10.726 & \\
\hline Bugojno & 248 & 10.760 & \\
\hline Olovo-Palež & 258 & 10.784 & \\
\hline Pale & 243 & 10.801 & \\
\hline Prozor & 251 & 10.820 & \\
\hline Olovo-Klis & 204 & 11.095 & \\
\hline Sokolac & 248 & 11.202 & \\
\hline Fojnica & 271 & 11.217 & \\
\hline B. Petrovac & 218 & & 11.946 \\
\hline Sig. & & 0.145 & 1.000 \\
\hline
\end{tabular}

Table 5. Descriptive indicators for height $(\mathrm{m})$ per provenances

\begin{tabular}{lcccccc}
\hline Provenance & $\mathrm{N}$ & Mean & $\begin{array}{c}\text { Standard } \\
\text { Deviation }\end{array}$ & Minimum & Maximum & $\begin{array}{c}\text { Variability } \\
\text { Coefficient }(\%)\end{array}$ \\
\hline Bosanski Petrovac & 218 & 9.1 & 2.7 & 1.5 & 14.7 & 29.4 \\
\hline Bugojno & 248 & 8.2 & 1.9 & 2.0 & 13.6 & 23.1 \\
\hline Fojnica & 271 & 8.6 & 1.9 & 2.5 & 12.9 & 22.4 \\
\hline Konjic & 258 & 8.1 & 1.6 & 2.4 & 14.8 & 19.7 \\
\hline Olovo-Klis & 204 & 8.1 & 1.4 & 2.5 & 11.0 & 17.1 \\
\hline Olovo Palež & 258 & 8.2 & 2.0 & 1.8 & 16.6 & 24.5 \\
\hline Pale & 243 & 8.1 & 1.9 & 1.8 & 12.9 & 23.3 \\
\hline Prozor & 251 & 8.3 & 1.9 & 2.4 & 14.5 & 23.1 \\
\hline Sokolac & 248 & 8.7 & 2.1 & 1.8 & 14.1 & 23.8 \\
\hline Total & 2199 & 8.4 & 2.0 & 1.5 & 16.6 & 23.6 \\
\hline
\end{tabular}


The average coefficient of variability for all provenances was $23.6 \%$. The highest coefficient of variation had the provenance of Bosanski Petrovac, 29.4\%, and the lowest provenance of Olovo - Klis, $17.1 \%$.
The variance analysis for the height of plants (Table 6) showed statistically significant differences among provenances for height at 0.05 level (Fizr.>Ftab, Sig.<0.005).

Table 6. Analysis of variance for height

\begin{tabular}{lccccc}
\hline Source of Variation & Sum of Squares & DF & Mean Square & F & Sig. \\
\hline Between Groups & 205.915 & 8 & 25.739 & 6.750 & 0.000 \\
\hline Within Groups & 8351.463 & 2190 & 3.813 & & \\
\hline Total & 8557.378 & 2198 & & & \\
\hline
\end{tabular}

Duncan's test divided provenances into three groups (Table 7).

Table 7. Duncan test for height

\begin{tabular}{llccc}
\hline \multirow{2}{*}{ Provenance } & \multirow{2}{*}{$\mathrm{N}$} & \multicolumn{3}{c}{ Subset for Alpha $=0.05$} \\
\cline { 3 - 5 } & & 1 & 2 & 3 \\
\hline Olovo-Klis & 204 & 8.095 & & \\
\hline Pale & 243 & 8.119 & & \\
\hline Konjic & 258 & 8.143 & & \\
\hline Bugojno & 248 & 8.170 & & \\
\hline Olovo Palež & 258 & 8.230 & & \\
\hline Prozor & 251 & 8.260 & & \\
\hline Fojnica & 271 & & 8.608 & \\
\hline Sokolac & 248 & & 8.681 & \\
\hline B. Petrovac & 218 & & & 9.062 \\
\hline Sig. & & 0.427 & 0.679 & 1.000 \\
\hline
\end{tabular}

Descriptive indicators for the basal area $\left(\mathrm{m}^{2}\right)$ per provenances are shown in Table 8 .

The average basal area of trees for all provenances was $0.005630 \mathrm{~m}^{2}$. Provenance Konjic had the lowest, and provenance Bosanski Petrovac the highest values for the basal area. The coefficient of variability was high for all provenances, from $47.4 \%$ for Olovo-Klis to $57.6 \%$ for provenances Pale and Prozor.

The variance analysis for the basal area (Table 9) showed statistically significant differences among provenances for height at 0.05 level (Fizr.>Ftab, Sig.<0.005).

Table 8. Descriptive indicators for basal area $\left(\mathrm{m}^{2}\right)$ per provenances

\begin{tabular}{lcccccc}
\hline Provenance & $\mathrm{N}$ & Mean & $\begin{array}{c}\text { Standard } \\
\text { Deviation }\end{array}$ & Minimum & Maximum & $\begin{array}{c}\text { Variability } \\
\text { Coefficient }(\%)\end{array}$ \\
\hline Bosanski Petrovac & 218 & 0.01213 & 0.00624 & 0.00071 & 0.02835 & 51.4 \\
\hline Bugojno & 248 & 0.00981 & 0.00525 & 0.00071 & 0.03142 & 53.5 \\
\hline Fojnica & 271 & 0.01079 & 0.00607 & 0.00071 & 0.03142 & 56.3 \\
\hline Konjic & 258 & 0.00964 & 0.00495 & 0.00126 & 0.03464 & 51.3 \\
\hline Olovo-Klis & 204 & 0.01029 & 0.00487 & 0.00071 & 0.02835 & 47.4 \\
\hline Olovo Palež & 258 & 0.00999 & 0.00562 & 0.00071 & 0.03801 & 56.3 \\
\hline Pale & 243 & 0.00998 & 0.00575 & 0.00126 & 0.03142 & 57.6 \\
\hline Prozor & 251 & 0.01003 & 0.00578 & 0.00126 & 0.03801 & 57.6 \\
\hline Sokolac & 248 & 0.01063 & 0.00563 & 0.00031 & 0.02545 & 53.0 \\
\hline Total & 2199 & 0.01034 & 0.00563 & 0.00031 & 0.03801 & 54.4 \\
\hline
\end{tabular}

Table 9. Analysis of variance for basal area

\begin{tabular}{lccccc}
\hline Source of Variation & Sum of Squares & DF & Mean Square & F & Sig. \\
\hline Between Groups & 0.001 & 8 & 0.000 & 4.239 & 0.000 \\
\hline Within Groups & 0.069 & 2190 & 0.000 & & \\
\hline Total & 0.070 & 2198 & & & \\
\hline
\end{tabular}


Duncan's test divided provenances into two groups, i.e., as for the trait of breast height diameter, provenance Bosanski Petrovac separates from other provenances (Table 10).

Descriptive statistics for volumes $\left(\mathrm{m}^{3}\right)$ per provenances are shown in Table 11.
Table 10. Duncan test for basal area

\begin{tabular}{lccc}
\hline \multirow{2}{*}{ Provenance } & \multirow{2}{*}{$\mathrm{N}$} & \multicolumn{2}{c}{ Subset for Alpha $=0.05$} \\
\cline { 3 - 4 } & & 1 & 2 \\
\hline Konjic & 258 & 0.00964 & \\
\hline Bugojno & 248 & 0.00981 & \\
\hline Pale & 243 & 0.00998 & \\
\hline Olovo Palež & 258 & 0.00999 & \\
\hline Prozor & 251 & 0.01003 & \\
\hline Olovo-Klis & 204 & 0.01029 & \\
\hline Sokolac & 248 & 0.01063 & \\
\hline Fojnica & 271 & 0.01079 & \\
\hline B. Petrovac & 218 & & 0.01213 \\
\hline Sig. & & 0.052 & 1.000 \\
\hline
\end{tabular}

Table 11. Descriptive statistics for volume $\left(\mathrm{m}^{3}\right)$ per provenances

\begin{tabular}{lcccccc}
\hline Provenance & $\mathrm{N}$ & Mean & $\begin{array}{c}\text { Standard } \\
\text { Deviation }\end{array}$ & Minimum & Maximum & $\begin{array}{c}\text { Variability } \\
\text { Coefficient }(\%)\end{array}$ \\
\hline Bosanski Petrovac & 218 & 0.089207 & 0.057383 & 0.00182 & 0.24102 & 64.3 \\
\hline Bugojno & 248 & 0.066005 & 0.041781 & 0.00242 & 0.24852 & 63.3 \\
\hline Fojnica & 271 & 0.075201 & 0.049310 & 0.00374 & 0.27351 & 65.6 \\
\hline Konjic & 258 & 0.063745 & 0.039109 & 0.00592 & 0.33875 & 61.4 \\
\hline Olovo-Klis & 204 & 0.066839 & 0.035996 & 0.00302 & 0.21102 & 53.9 \\
\hline Olovo Palež & 258 & 0.067931 & 0.046590 & 0.00218 & 0.41075 & 68.6 \\
\hline Pale & 243 & 0.067189 & 0.046327 & 0.00304 & 0.26019 & 69.0 \\
\hline Prozor & 251 & 0.068083 & 0.046129 & 0.00412 & 0.36574 & 67.8 \\
\hline Sokolac & 248 & 0.074876 & 0.047475 & 0.00142 & 0.24265 & 63.4 \\
\hline Total & 2199 & 0.070845 & 0.046420 & 0.00142 & 0.41075 & 65.5 \\
\hline
\end{tabular}

The average volume of trees for all provenances was $0.070845 \mathrm{~m}^{3}$. Provenance Olovo-Klis had the lowest average value of the basal area, and provenance Bosanski Petrovac the highest. The average coefficient of variability was $65.5 \%$.

The variance analysis for volume (Table 12) showed statistically significant differences among provenances for height at 0.05 level (Fizr.>Ftab, Sig. <0.005).

Duncan's test divided provenances into three groups. First two groups overlapped, and provenance Bosanski Petrovac separated into a different group, as shown in Table 13.

Table 12. Analysis of variance for volume

\begin{tabular}{lccccc}
\hline Source of Variation & Sum of Squares & DF & Mean Square & F & Sig. \\
\hline Between Groups & 0.112 & 8 & 0.014 & 6.637 & 0.000 \\
\hline Within Groups & 4.624 & 2190 & 0.002 & & \\
\hline Total & 4.736 & 2198 & & & \\
\hline
\end{tabular}

Table 13. Duncan test for volume

\begin{tabular}{|c|c|c|c|c|}
\hline \multirow{2}{*}{ Provenance } & \multirow{2}{*}{$\mathrm{N}$} & \multicolumn{3}{|c|}{ Subset for Alpha $=0.05$} \\
\hline & & 1 & 2 & 3 \\
\hline Konjic & 258 & 0.06375 & & \\
\hline Bugojno & 248 & 0.06600 & 0.06600 & \\
\hline Olovo-Klis & 204 & 0.06684 & 0.06684 & \\
\hline Pale & 243 & 0.06719 & 0.06719 & \\
\hline Olovo Palež & 258 & 0.06793 & 0.06793 & \\
\hline Prozor & 251 & 0.06808 & 0.06808 & \\
\hline Sokolac & 248 & & 0.07488 & \\
\hline Fojnica & 271 & & 0.07520 & \\
\hline B. Petrovac & 218 & & & 0.08921 \\
\hline Sig. & & 0.375 & 0.056 & 1.000 \\
\hline
\end{tabular}


To analyse the effects of blocks on the growth of silver fir in the provenance test, we performed univariate analysis (Table 14).

Table 14. Average values of DBH $(\mathrm{cm})$ per provenances and blocks

\begin{tabular}{|c|c|c|c|c|c|c|c|c|c|c|c|c|}
\hline \multirow{2}{*}{ Provenance } & \multicolumn{2}{|c|}{ Block 1} & \multicolumn{2}{|c|}{ Block 2} & \multicolumn{2}{|c|}{ Block 3} & \multicolumn{2}{|c|}{ Block 4} & \multicolumn{2}{|c|}{ Block 5} & \multicolumn{2}{|c|}{ Total } \\
\hline & $\mathrm{N}$ & Mean & $\mathrm{N}$ & Mean & $\mathrm{N}$ & Mean & $\mathrm{N}$ & Mean & $\mathrm{N}$ & Mean & $\mathrm{N}$ & Mean \\
\hline B. Petrovac & 50 & 12.1 & 23 & 12.5 & 38 & 10.7 & 52 & 13.9 & 55 & 10.6 & 218 & 11.9 \\
\hline Bugojno & 46 & 10.9 & 48 & 10.5 & 46 & 11.0 & 56 & 11.0 & 52 & 10.4 & 248 & 10.8 \\
\hline Fojnica & 53 & 11.0 & 52 & 10.9 & 60 & 11.5 & 54 & 11.5 & 52 & 11.2 & 271 & 11.2 \\
\hline Konjic & 41 & 11.5 & 57 & 10.8 & 52 & 9.6 & 56 & 10.6 & 52 & 11.3 & 258 & 10.7 \\
\hline Olovo-Klis & 25 & 11.6 & 42 & 12.2 & 53 & 11.1 & 52 & 10.0 & 32 & 11.1 & 204 & 11.1 \\
\hline Olovo Palež & 50 & 9.6 & 42 & 11.1 & 58 & 11.0 & 54 & 11.5 & 54 & 10.6 & 258 & 10.8 \\
\hline Pale & 36 & 10.2 & 52 & 8.8 & 47 & 12.1 & 50 & 11.8 & 58 & 11.0 & 243 & 10.8 \\
\hline Prozor & 43 & 11.1 & 56 & 11.7 & 53 & 10.2 & 47 & 10.7 & 52 & 10.4 & 251 & 10.8 \\
\hline Sokolac & 42 & 11.4 & 53 & 11.0 & 49 & 10.5 & 50 & 12.4 & 54 & 10.8 & 248 & 11.2 \\
\hline Total & 386 & 11.0 & 425 & 10.9 & 456 & 10.9 & 471 & 11.5 & 461 & 10.8 & 2199 & 11.0 \\
\hline
\end{tabular}

The highest average value of $\mathrm{DBH}$ for all provenances was in block $4(11.5 \mathrm{~cm})$, and lowest in block $5(10.8 \mathrm{~cm})$.

Tests of Between-Subjects Effects table (Table 15) for DBH showed the presence of a statistically significant effect of interaction between blocks and provenances (Fizr.>Ftab.,
Sig. $<0.005$ ), which means that even though the environmental conditions are similar in the whole surface of provenance test, small differences in microclimate caused the differences among provenances regarding values of diameter at breast height.

Table 15. Tests of between subject effects for breast height diameter

\begin{tabular}{lccccc}
\hline Source & $\begin{array}{c}\text { Type III Sum of } \\
\text { Squares }\end{array}$ & DF & Mean Square & F & Sig. \\
\hline Corrected Model & $1549.746^{\mathrm{a}}$ & 44 & 35.221 & 3.773 & 0.000 \\
\hline Intercept & 258132.102 & 1 & 258132.102 & 27648.170 & 0.000 \\
\hline Block & 133.100 & 4 & 33.275 & 3.564 & 0.007 \\
\hline Provenance & 268.601 & 8 & 33.575 & 3.596 & 0.000 \\
\hline $\begin{array}{l}\text { Block * } \\
\text { Provenance }\end{array}$ & 1135.665 & 32 & 35.490 & 3.801 & 0.000 \\
\hline Error & 20110.429 & 2154 & 9.336 & & \\
\hline Total & 288954.960 & 2199 & & & \\
\hline Corrected Total & 21660.174 & 2198 & & & \\
\hline
\end{tabular}

a. R Squared $=.072$ (Adjusted R Squared $=.053$ )

In the graphical representation of estimated marginal means for the trait of DBH (Figure 1), it is visible that there is a statistically significant interaction between blocks and provenances. Provenance Bosanski Petrovac showed the highest estimated marginal mean values in block 1 , block 2 , and block 4 , but the value among others in block 3 and block 5. Provenance Pale showed the lowest estimated marginal mean in block 2, but the highest in block 3 (Table 16). 


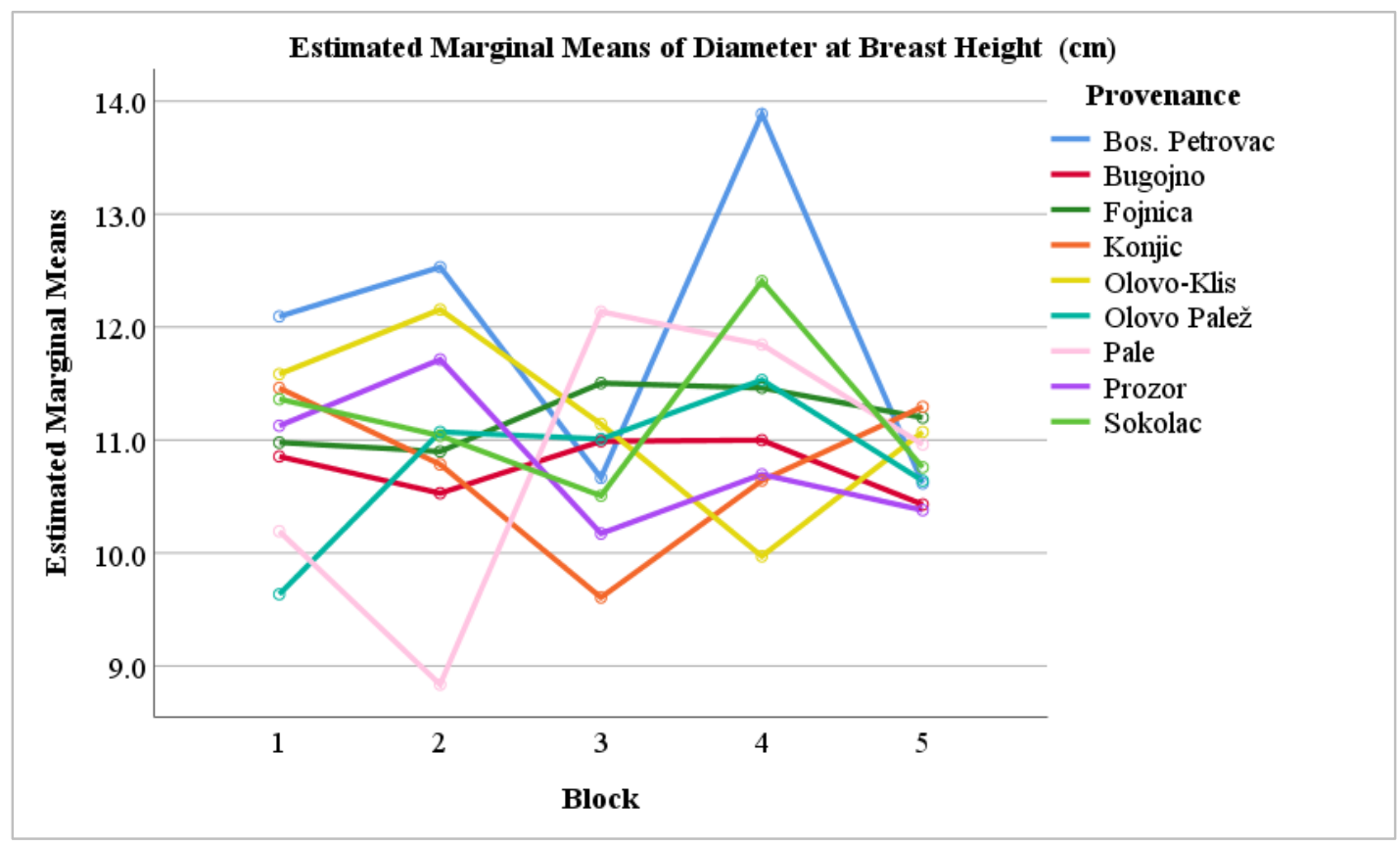

Figure 1. Estimated marginal means of DBH

Table 16. Average values of height $(\mathrm{m})$ per provenances and blocks

\begin{tabular}{|c|c|c|c|c|c|c|c|c|c|c|c|c|}
\hline \multirow{2}{*}{ Provenance } & \multicolumn{2}{|c|}{ Block 1} & \multicolumn{2}{|c|}{ Block 2} & \multicolumn{2}{|c|}{ Block 3} & \multicolumn{2}{|c|}{ Block 4} & \multicolumn{2}{|c|}{ Block 5} & \multicolumn{2}{|c|}{ Total } \\
\hline & $\mathrm{N}$ & Mean & $\mathrm{N}$ & Mean & $\mathrm{N}$ & Mean & $\mathrm{N}$ & Mean & $\mathrm{N}$ & Mean & $\mathrm{N}$ & Mean \\
\hline B. Petrovac & 50 & 9.6 & 23 & 8.3 & 38 & 7.7 & 52 & 11.5 & 55 & 7.5 & 218 & 9.1 \\
\hline Bugojno & 46 & 8.1 & 48 & 7.9 & 46 & 8.4 & 56 & 8.5 & 52 & 7.9 & 248 & 8.2 \\
\hline Fojnica & 53 & 8.4 & 52 & 8.5 & 60 & 9.3 & 54 & 8.5 & 52 & 8.3 & 271 & 8.6 \\
\hline Konjic & 41 & 8.4 & 57 & 8.0 & 52 & 7.6 & 56 & 8.1 & 52 & 8.6 & 258 & 8.1 \\
\hline Olovo-Klis & 25 & 8.1 & 42 & 8.5 & 53 & 8.0 & 52 & 7.6 & 32 & 8.4 & 204 & 8.1 \\
\hline Olovo Palež & 50 & 7.4 & 42 & 8.2 & 58 & 8.8 & 54 & 8.5 & 54 & 8.2 & 258 & 8.2 \\
\hline Pale & 36 & 7.5 & 52 & 6.7 & 47 & 8.7 & 50 & 9.2 & 58 & 8.3 & 243 & 8.1 \\
\hline Prozor & 43 & 8.2 & 56 & 8.8 & 53 & 8.8 & 47 & 7.5 & 52 & 7.9 & 251 & 8.3 \\
\hline Sokolac & 42 & 8.7 & 53 & 8.2 & 49 & 8.1 & 50 & 10.2 & 54 & 8.3 & 248 & 8.7 \\
\hline Total & 386 & 8.3 & 425 & 8.1 & 456 & 8.4 & 471 & 8.8 & 461 & 8.1 & 2199 & 8.4 \\
\hline
\end{tabular}

The highest average value of height for all provenances was in block $4(8.8 \mathrm{~m})$, and lowest in block 2 and block $5(8.1 \mathrm{~m})$.

Tests of Between-Subjects Effects table (Table 17) for the trait of height showed that there is a statistically significant interaction between blocks and provenances (Fizr.>Ftab.,
Sig. $<0.005)$, which means that even though the environmental conditions are similar in the whole surface of provenance test, small differences in microclimate caused the differences among provenances regarding values of diameter at breast height.

Table 17. Tests of between subject effects for height

\begin{tabular}{lccccc}
\hline Source & Type III Sum of Squares & DF & Mean Square & F & Sig. \\
\hline Corrected Model & $1330.396^{\mathrm{a}}$ & 44 & 30.236 & 9.012 & 0.000 \\
\hline Intercept & 147578.326 & 1 & 147578.326 & 43985.682 & 0.000 \\
\hline Block & 147.643 & 4 & 36.911 & 11.001 & 0.000 \\
\hline Provenance & 159.503 & 8 & 19.938 & 5.942 & 0.000 \\
\hline Block * Provenance & 970.777 & 32 & 30.337 & 9.042 & 0.000 \\
\hline Error & 7226.982 & 2154 & 3.355 & & \\
\hline Total & 162668.920 & 2199 & & & \\
\hline Corrected Total & 8557.378 & 2198 & & & \\
\hline
\end{tabular}

a. R Squared $=0.155$ (Adjusted R Squared $=.138$ ) 
In the graphical representation of estimated marginal means for the trait of height (Figure 2), it is visible that there is a statistically significant interaction between blocks and provenances. Provenance
Bosanski Petrovac showed the highest estimated marginal mean values in block 1 , and block 4 , but the value among others in block 2 and block 3 , and the lowest value in block 5 (Table 18).

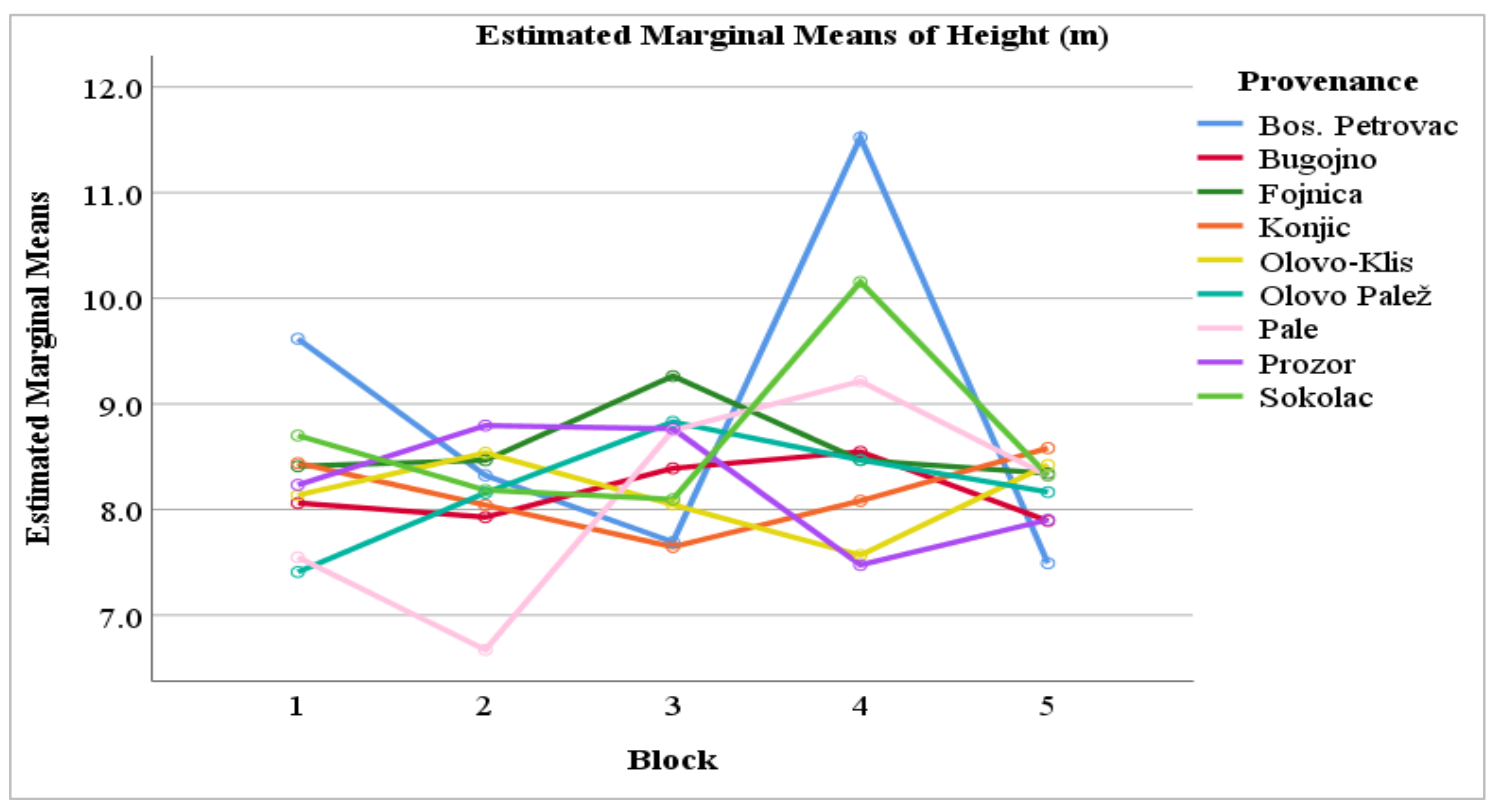

Figure 2. Estimated marginal means of height

Table 18. Average values of basal area $\left(\mathrm{m}^{2}\right)$ per provenances and blocks

\begin{tabular}{lcccccccccccc}
\hline \multirow{2}{*}{ Provenance } & \multicolumn{2}{c}{ Block 1 } & \multicolumn{2}{c}{ Block 2 } & \multicolumn{2}{c}{ Block 3 } & \multicolumn{2}{c}{ Block 4 } & \multicolumn{2}{c}{ Block 5 } & \multicolumn{2}{c}{ Total } \\
\cline { 2 - 14 } & $\mathrm{N}$ & Mean & $\mathrm{N}$ & Mean & $\mathrm{N}$ & Mean & $\mathrm{N}$ & Mean & $\mathrm{N}$ & Mean & $\mathrm{N}$ & Mean \\
\hline B. Petrovac & 50 & 0.01204 & 23 & 0.01299 & 38 & 0.00989 & 52 & 0.01592 & 55 & 0.00983 & 218 & 0.01213 \\
\hline Bugojno & 46 & 0.00964 & 48 & 0.00927 & 46 & 0.01066 & 56 & 0.01023 & 52 & 0.00925 & 248 & 0.00981 \\
\hline Fojnica & 53 & 0.01006 & 52 & 0.01004 & 60 & 0.01128 & 54 & 0.01141 & 52 & 0.01108 & 271 & 0.01079 \\
\hline Konjic & 41 & 0.01053 & 57 & 0.00982 & 52 & 0.00777 & 56 & 0.00948 & 52 & 0.01079 & 258 & 0.00964 \\
\hline Olovo-Klis & 25 & 0.01091 & 42 & 0.01238 & 53 & 0.01022 & 52 & 0.00848 & 32 & 0.01011 & 204 & 0.01029 \\
\hline Olovo Palež & 50 & 0.00786 & 42 & 0.01066 & 58 & 0.01028 & 54 & 0.01140 & 54 & 0.00972 & 258 & 0.00999 \\
\hline Pale & 36 & 0.00835 & 52 & 0.00664 & 47 & 0.01260 & 50 & 0.01177 & 58 & 0.01031 & 243 & 0.00998 \\
\hline Prozor & 43 & 0.01067 & 56 & 0.01158 & 53 & 0.00857 & 47 & 0.01024 & 52 & 0.00915 & 251 & 0.01003 \\
\hline Sokolac & 42 & 0.01133 & 53 & 0.01006 & 49 & 0.00937 & 50 & 0.01310 & 54 & 0.00949 & 248 & 0.01063 \\
\hline Total & 386 & 0.01013 & 425 & 0.01017 & 456 & 0.01007 & 471 & 0.01131 & 461 & 0.00996 & 2199 & 0.01034 \\
\hline
\end{tabular}

As expected, the highest average value of the basal area was in block 4, and lowest in block 5, as for the traits of breast height diameter.

Tests of between-subjects effects table (Table 19) for the trait of basal area showed that there was a statistically significant interaction between blocks and provenances (Fizr.>Ftab., Sig.<0.005), as it was the case with the diameter at breast height which we used for the calculation of basal area, where the small differences in environmental conditions among blocks cause differences in growth of provenances. 
Table 19. Tests of between subject effects for basal area

\begin{tabular}{lccccc}
\hline Source & Type III Sum of Squares & DF & Mean Square & F & Sig. \\
\hline Corrected Model & $.005^{\mathrm{a}}$ & 44 & 0.000 & 4.160 & 0.000 \\
\hline Intercept & .228 & 1 & 0.228 & 7640.357 & 0.000 \\
\hline Block & .001 & 4 & 0.000 & 4.738 & 0.001 \\
\hline Provenance & .001 & 8 & 0.000 & 4.139 & 0.000 \\
\hline Block * Provenance & .004 & 32 & 0.000 & 4.008 & 0.000 \\
\hline Error & .064 & 2154 & $2.981 \mathrm{E}-5$ & & \\
\hline Total & .305 & 2199 & & & \\
\hline Corrected Total & .070 & 2198 & & & \\
\hline a. R Squared $=.155$ (Adjusted R Squared $=.138)$ & & &
\end{tabular}

In the graphical representation of estimated marginal means for the trait of basal area (Figure 3), it is visible that there is a statistically significant interaction between blocks and provenances.

Provenance Bosanski Petrovac showed the highest estimated marginal mean values in block 1 , block 2 and block 4 , but the value among others in block 3 and block 5 . Provenance Pale showed the lowest estimated marginal mean in block 2, but the highest in block 3 .

Results of average volume per provenance and blocks are shown in Table 20.

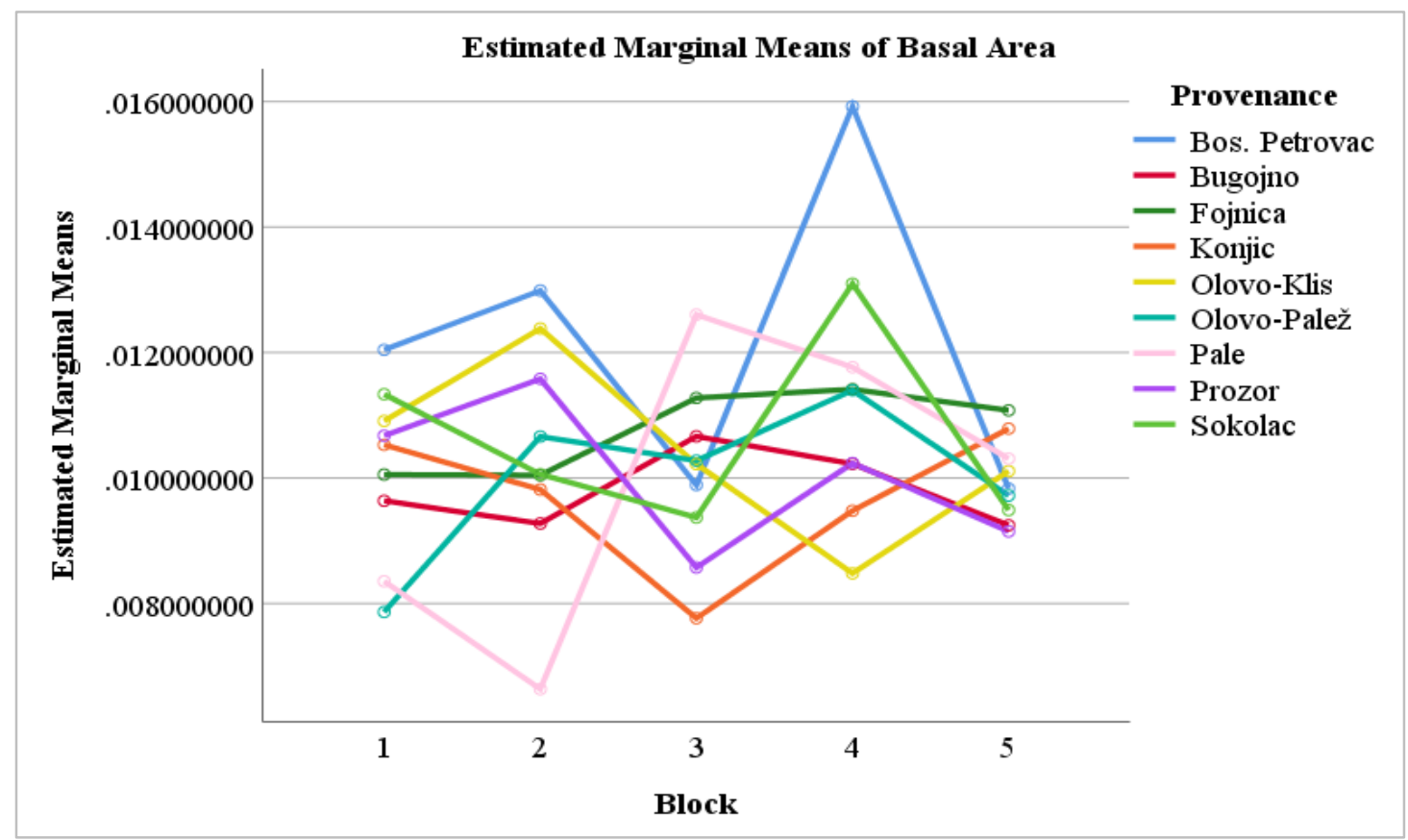

Figure 3. Estimated marginal means of basal area

Table 20. Average values of volume $\left(\mathrm{m}^{3}\right)$ per provenances and blocks

\begin{tabular}{|c|c|c|c|c|c|c|c|c|c|c|c|c|}
\hline \multirow{2}{*}{ Provenance } & \multicolumn{2}{|c|}{ Block 1} & \multicolumn{2}{|c|}{ Block 2} & \multicolumn{2}{|c|}{ Block 3} & \multicolumn{2}{|c|}{ Block 4} & \multicolumn{2}{|c|}{ Block 5} & \multicolumn{2}{|c|}{ Total } \\
\hline & $\mathrm{N}$ & Mean & $\mathrm{N}$ & Mean & $\mathrm{N}$ & Mean & $\mathrm{N}$ & Mean & $\mathrm{N}$ & Mean & $\mathrm{N}$ & Mean \\
\hline B. Petrovac & 50 & 0.08973 & 23 & 0.08673 & 38 & 0.06544 & 52 & 0.13485 & 55 & 0.06304 & 218 & 0.08921 \\
\hline Bugojno & 46 & 0.06336 & 48 & 0.06067 & 46 & 0.07526 & 56 & 0.07114 & 52 & 0.05955 & 248 & 0.06601 \\
\hline Fojnica & 53 & 0.06696 & 52 & 0.06944 & 60 & 0.08255 & 54 & 0.07877 & 52 & 0.07717 & 271 & 0.07520 \\
\hline Konjic & 41 & 0.06959 & 57 & 0.06373 & 52 & 0.04993 & 56 & 0.06236 & 52 & 0.07447 & 258 & 0.06375 \\
\hline Olovo-Klis & 25 & 0.07064 & 42 & 0.08287 & 53 & 0.06580 & 52 & 0.05354 & 32 & 0.06615 & 204 & 0.06684 \\
\hline Olovo Palež & 50 & 0.04872 & 42 & 0.07328 & 58 & 0.07211 & 54 & 0.07985 & 54 & 0.06516 & 258 & 0.06793 \\
\hline Pale & 36 & 0.05140 & 52 & 0.03948 & 47 & 0.08788 & 50 & 0.08444 & 58 & 0.07019 & 243 & 0.06719 \\
\hline Prozc & 43 & 0.07179 & 56 & 0.08075 & 53 & 0.06080 & 47 & 0.06726 & 52 & 0.05954 & 251 & 0.06808 \\
\hline Sokolac & 42 & 0.08104 & 53 & 0.06596 & 49 & 0.06289 & 50 & 0.10342 & 54 & 0.06329 & 248 & 0.07488 \\
\hline Total & 386 & 0.06826 & 425 & 0.06772 & 456 & 0.06930 & 471 & 0.08151 & 461 & 0.06653 & 2199 & 0.07085 \\
\hline
\end{tabular}


As expected, the highest average value of volume was in block 4, and lowest in block 5 , as for the traits of breast height diameter and height.

Tests of between-subjects effects table (Table 21) for the trait of volume showed that there was a statistically significant interaction between blocks and provenances (Fizr.>Ftab., Sig.<0.005), as it was the case with the traits of the diameter at breast height and the height, where differences in environmental conditions among blocks caused the differences in the growth of provenances.

Table 21. Tests of between subject effects for volume

\begin{tabular}{lccccc}
\hline Source & Type III Sum of Squares & DF & Mean Square & F & Sig. \\
\hline Corrected Model & $0.526^{\mathrm{a}}$ & 44 & 0.012 & 6.122 & 0.000 \\
\hline Intercept & 10.639 & 1 & 10.639 & 5443.656 & 0.000 \\
\hline Block & 0.069 & 4 & 0.017 & 8.804 & 0.000 \\
\hline Provenance & 0.095 & 8 & 0.012 & 6.066 & 0.000 \\
\hline Block * Provenance & 0.344 & 32 & 0.011 & 5.502 & 0.000 \\
\hline Error & 4.210 & 2154 & 0.002 & & \\
\hline Total & 15.773 & 2199 & & & \\
\hline Corrected Total & 4.736 & 2198 & & &
\end{tabular}

In the graphical representation of estimated marginal means for the trait of volume (Figure 4), it is visible that there is a statistically significant interaction between blocks and provenances. Provenance Bosanski Petrovac showed the highest estimated marginal mean values in block 1 , block 2 and block 4, but the value among others in block 3 and block 5. Provenance Pale showed the lowest estimated marginal mean in block 2 , but the highest in block 3 .

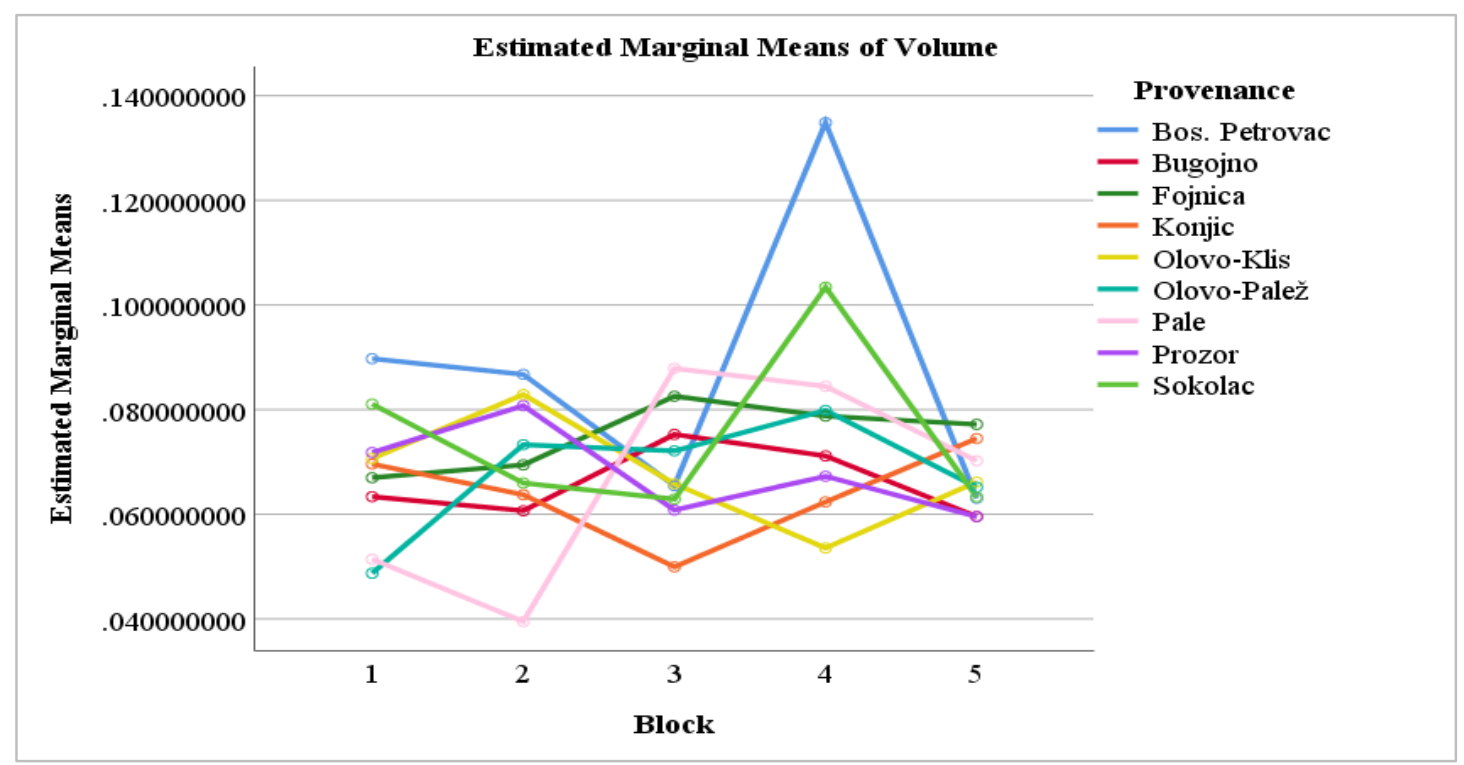

Figure 4. Estimated marginal means of volume

\section{Discussion}

Provenance tests of silver fir in Europe started in Switzerland and were focused on the research of individual growth of trees (Engler, 1905).
Larsen (1986) investigated the geographic variability of silver fir and found that provenances from South-East Europe showed significant differences in increment between each other, and also comparing to Carpathian provenances. 
Mekić (1988) found a high variability of morphological and physiological indicators of Calabrian provenances, while the Central European provenances showed homogeneity.

Investigations of morphological traits in provenance cultures from central and southern Italy showed significant intrapopulation and interpopulation variation of silver fir (Ducci, 1991).

Mekić \& Larsen (1991) researched the geographic variability of silver fir in Europe in 15 provenances when they were six-yearold. Italian provenances had a significantly higher increment of height and diameter than provenances from Central and Eastern Europe.

In France, the provenance trial of common fir was founded in 1963 with 19 French and two Romanian provenances (Lapus and Prahova). Foreign provenances with their characteristics were control populations to local ones. The range of height increment variability was up to $27 \%$ higher in foreign than in local provenances (Kajba, 2001).

Ratknić et al. (2002) researched the provenance test of silver fir in Serbia and found statistically significant differences among observed provenances.

Ivanković et al. (2006) researched in provenance test in Croatia, which included 18 provenances from Croatia and two from Slovenia. By variance analysis, they found statistically significant differences between provenances in growth dynamics.

Memišević et. al. (2016) researched phenological phases of leafing of silver fir in the same provenance tests. They didn't found statistically significant differences among provenances for dates of starting of individual phases, nor for the duration of phases.

Halilović (2008), Halilović et al. (2009a, $2009 \mathrm{~b}, 2013)$ researched the younger age of plants on the same provenance test and found statistically significant differences in morphological indicators among provenances.

In this research, we analyzed morphological traits of 27-year-old trees from nine provenances on Delimusa experimental plot.

The variance analysis showed statistically significant differences among provenances for two measured traits (breast height diameter, height, and two calculated traits (basal area and volume).

Konjic provenance had the lowest, and Bosanski Petrovac provenance the highest average DBH. Obtained results are similar to those of research of Halilović (2008) on 20year-old plants in the same experimental plot, where Pale provenance also had the lowest, and provenance of Bosanski Petrovac the highest average DBH.

Provenances Konjic, Olovo-Klis, and Pale had the lowest, and Bosanski Petrovac the highest average height. The results correspond to results obtained by Halilović (2008) in the same provenance test of 20 -year-old plants when Olovo Klis provenance had the lowest, and Bosanski Petrovac the highest average height. In research of the same provenances on three-, four- and five-year-old seedlings, Mekić (1991) found statistically significant differences in height among provenances in the age of three and four, while there were no statistically significant differences among provenances at age five. Ratknić et al. (2002), in the test of same provenances in Priboj, Serbia, obtained the lowest average height for the Olovo-Klis provenance, and the highest for Bosanski Petrovac, as in this research. As for the trait of diameter at breast height, provenance Konjic had the lowest, and provenance Bosanski Petrovac the highest average value of the basal area.

Provenance Olovo-Klis had the lowest average value of volume, and provenance Bosanski Petrovac the highest.

Variance analysis for all traits showed statistically significant differences among provenances.

Univariate analysis showed the effects of blocks and interaction block $\mathrm{x}$ provenance. Maximum average values for all traits provenances showed in block 4 . It means that small differences in ecological conditions can cause differences in the growth of silver fir.

This research included a small part of the silver fir natural distribution range, so we did not expect significant differences among provenances, especially because of the young age of the provenance test.

The Dinaric Mountains region is very specific when it comes to environmental conditions. On a very small area, there is a variety of climatic, edaphic, orographic, and 
other factors affecting the differentiation of ecotypes, especially in the area of Central Bosnia (Stefanović et al., 1983). Therefore, experts consider that forest tree species from the Dinaric Mountains show higher variability compared to the same species from the north (Ballian \& Čabaravdić, 2005; Ballian \& Halilović, 2016)

\section{Conclusion}

Based on the written above, we can conclude that the results of this research confirmed the existence of variability of Bosnian-Herzegovinian provenances of silver fir regard to morphological traits. In other words, there are differences among populations from different ecological niches, i.e. differences in the ecology of habitats cause morphological differentiation among populations.

Provenance Bosanski Petrovac showed the highest values of the height, diameter at breast height, basal area, and volume of the trees, which implies it is the best provenance for the further activities on seed collecting and producing planting material for afforestation in Bosnia and Herzegovina.

Morphological research of provenances on this experimental plot should be continued to obtain more reliable results of morphological traits at older plants, as well as determine the juvenile-adult correlation for these traits.

\section{Ethics Committee Approval N/A}

\section{Peer-review}

Externally peer-reviewed.

\section{Author Contributions}

Conceptualization:

D.B., M.M.H.; Investigation: D.B., M.M.H., V.H., A.A.; Material and Methodology: D.B., M.M.H., V.H., A.A.; Supervision: D.B.; Visualization: M.M.H., A.A; Writing-Original Draft: M.M.H.; Writing-review \& Editing: D.B., M.M.H., V.H., A.A.; Other: All authors have read and agreed to the published version of manuscript.

\section{Conflict of Interest}

The authors have no conflicts of interest to declare.

\section{Funding}

The authors declared that this study has received no financial support.

\section{References}

Ballian, D. \& Čabaravdić, A. (2005). Međupopulacijska varijabilnost nekih morfoloških svojstava obične jele (Abies alba Mill.) iz središnje Bosne. Radovi Šumarskog instituta, 40(1), 5-18, Jastrebarsko.

Ballian, D. \& Halilović, V. (2016). Varijabilnost obične jele (Abies alba Mill.) u Bosni i Hercegovini. Udruženje inžinjera i tehničara šumarstva Federacije Bosne i Hercegovine i Silva Slovenica, Sarajevo, Ljubljana.

Ducci, F. (1991). Morphological variation in silver fir (Abies alba Mill.) seedings from provenances in central and southern Italy. Annali del 'Instituto Sperimentale per la Selvicoltura, publ. 1944, 22, 53-73.

Engler, A. (1905). Einfluss der Prevenienz des Samens auf die Eigenschaften der forsticher Gewächsen. Mitt. Schweiz. Anst.forstl. Versuchswes., 8, 81-235. (iz: Halilović, V. 2008: Varijabilnost morfoloških svojstava obične jele (Abies alba Mill.) u pokusu provenijencija Delimusa na području Olova. Šumarski fakultet Univerziteta u Sarajevu (magistarski rad).

Fukarek, P. (1970). Areali rasprostranjenosti bukve, jele i smrče na području Bosne i Hercegovine. Akademija nauka i umjetnosti $\mathrm{BiH}$, radovi XXXIX, 11, 231-256.

Halilović, V. (2008). Varijabilnost morfoloških svojstava obične jele (Abies alba Mill.) u pokusu provenijencija Delimusa na području Olova. Šumarski fakultet Univerziteta u Sarajevu (magistarski rad).

Halilović, V., Ballian, D., Mekić, F. \& Višnjić, Ć. (2009a). Morphological analysis of some assimilation characteristics of the silver fir (Abies alba Mill.) in the experiment Delimusa. Works of the Faculty of Forestry Univesity of Sarajevo, 2, 15-25.

Halilović, V., Mekić, F., Višnjić, Ć. \& Ballian, D. (2009b). Varijabilnost visinskog prirasta devet provenijencija obične jele (Abies alba Mill.) iz $\mathrm{BiH}$ u pokusu „Delimusa“ kod Olova. Naše šume Sarajevo, 14-15, godina VIII, 11-19.

Halilović, V., Mekić., F., Višnjić, Ć. \& Ballian, D. (2013). Variability of some morphological features of silver fir (Abies alba Mill.) in a national test of proveniences/Varijabilnost nekih morfoloških svojstava obične jele (Abies alba Mill.) u nacionalnom pokusu provenijencija. Works of the Faculty of Forestry University of Sarajevo, 1, 55-65. 
Ivanković, M., Bogdan, S., Marjanović, H., Kajba, D. \& Gračan, J. (2006). Dinamika rasta i razvoja terminalnog izbojka biljaka $\mathrm{u}$ pokusima provenijencija obične jele (Abies alba Mill.) u Hrvatskoj. Radovi Šumarskog instituta Jastrebarsko. 41(1-2), 17-24.

Kajba, D. (2001). Unutarpopulacijska i međupopulacijska varijabilnost obične jele. Obična jela u Hrvatskoj, Zagreb, 322-345.

Larsen, J. B. (1986). Geography variation in silver fir (Abies alba Mill.) growth rate and frost resistance. Fortwissenschaflitches Centralblatt, Gottingen, 105, 396-406.

Matić, V., Drinić, P., Pavlič, J., Prolić, N., Stojanović, O., Vukmirović, V. \& Koprivica, M. (1990). Tablice taksacionih elemenata visokih i izdanačkih šuma $u$ Bosni i Hercegovini, Šumarski fakultet Univerziteta $\mathrm{u}$ Sarajevu, Sarajevo.

Mekić, F. \& Larsen, J. B. (1991). The geographic variation in European silver fir (Abies alba Mill.) gas exchange and needle cast in relation to needle age, growth rate, dry matter partitioning and wood density by 15 different provenances at age 6. Silvae Genetica, 40(5-6), 118-198.

Mekić, F. (1988). Gaswechselphysiologische und morfologische Untersuchungen an $5-6$ jaehrigen Weisstannen-Provenienze (Abies alba Mill.). Dissertation, Institut für Waldbau der Univerzität Göttingen, 1-144.

Mekić, F. (1991). Morfološke karakteristike petogodišnjih sadnica jele (Abies alba Mill.) sa devet lokaliteta u BiH. Univerzitet u Beogradu, Glasnik Šumarskog fakulteta, Beograd br. 73. str. 141-152.

Memišević Hodžić, M., Džakmić, J. \& Ballian, D. (2016). Phenological variability of certain silver fir populations (Abies alba, Mill.) in Bosnia and Herzegovina/ Fenološka varijabilnost nekih populacija obične jele (Abies alba, MILL.) u Bosni i Hercegovini. Works of the Faculty of Forestry University of Sarajevo No. 2, 2016 (1-9).

Ratknić, K., Vučković, M., Stamenković, V. \& Stajić, B. (2002). Silver fir (Abies alba Mill) provenance test in southwestern Serbia. 10. Internationalen IUFRO-Tannen- symposium am 16. - 20. Sept. 2002 an der FAWF in Trippstadt, 59-67.

Stefanović, V., Beus, V., Burlica, Č., Dizdarević, H. \& Vukorep, I. (1983). Ekološko vegetacijska rejonizacija Bosne i Hercegovine. Radovi Šum. fakulteta i Instituta za šumarstvo, Posebno izdanje 17, Sarajevo, 51 str.

Usčuplić, M. (1992). Uticaj sistema gazdovanja na pojavu imele (Viscum album L.). Glasnik Šmarskog fakulteta u Beogradu, Str. 7-18. 